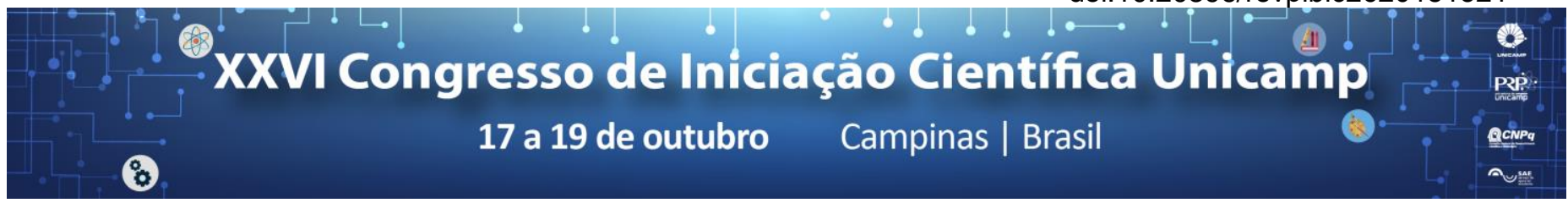

\title{
Evaluation of the conditions for bacterial biofilm removal from E. coli by proteases present in enzymatic detergents
}

\author{
Thiely M. Bresciani ${ }^{\star}$, Marina R. P. Garcia, Mariana S. Derami, Hiroshi Aoyama, Domingos da S. Leite, Márcio \\ André Miranda
}

\begin{abstract}
The development of effective cleaning products to remove microbial loads has been of extreme importance for the Sterilization Centers of Dental-Medical-Hospital Materials. The addition of enzymes to these products has promoted a beneficial effect, which efficiency depended on the biofilm and the enzymes evaluated. Thus, the objective of this work was to analyze the efficiency of such cleaning agents that contain enzymes of the protease class in the removal of bacterial biofilm of $\mathrm{E}$. coli under different conditions of time, temperature and $\mathrm{pH}$.
\end{abstract}

\section{Key words:}

Proteases, bacterial biofilm, E. coli.

\section{Introduction}

One of the major health care challenge in hospital infections is to get an efficient way to remove dirtiness and bacterial biofilms from medical devices avoiding high costs for the health care system ${ }^{1}$. Corrosive chemicals and high temperatures can not be used for this purpose due to the delicacy of some medical devices, constituting a great difficulty of cleaning in materials centers and sterilization. In this way, softer solutions, such as enzymatic detergents, must be carefully developed to ensure effective performance. The objective of this work was to evaluate the efficiency of these cleaning agents containing enzymes of the protease class in the removal of the bacterial biofilm of $E$. coli under different conditions of time, temperature and $\mathrm{pH}$.

\section{Results and Discussion}

Escherichia coli ATCC 35218 biofilm was developed in $\mathrm{BHI}$ medium for $24 \mathrm{~h}$ at $37^{\circ} \mathrm{C}$ in 96 -well plates for further analysis of biofilm removal ${ }^{2}$. Two enzymes of the class of the serine proteases (E1 and E2) at concentrations of $0.5 \%$ and $5.0 \%$, diluted in base detergent were evaluated. The following conditions were used: $\mathrm{pH}$ values of 6.0 and 7.0, time exposure of $0.5 \mathrm{~h}$ and $2.0 \mathrm{~h}$, and temperatures of $30^{\circ} \mathrm{C}$ and $45^{\circ} \mathrm{C}$. $0.25 \%$ SDS and $0.9 \% \mathrm{NaCl}$ were used as positive and negative controls, respectively. The residual biomass and the cell viability were determined using crystal violet and tetrazolium salt, respectively. At the different $\mathrm{pH}$ values evaluated, E1 and E2 were able to remove the bacterial biofilm according to the results presented in Chart 1.

Chart 1. Summary of biofilm removal capacity for the proposed enzymes.

\begin{tabular}{|c|c|c|c|}
\hline \multirow{2}{*}{$\begin{array}{c}\text { Enzyme diluted } \\
\text { in standard } \mathrm{H}_{2} \mathrm{O}\end{array}$} & $\begin{array}{c}\text { Biofilm } \\
\text { removal } \\
\text { capability }\end{array}$ & $\begin{array}{c}\text { Total } \\
\text { biomass }\end{array}$ & $\begin{array}{c}\text { Bacterial } \\
\text { viability }\end{array}$ \\
\hline E1 & \multirow{2}{*}{ Yes } & ++ & +++ \\
\cline { 1 - 1 } 2 & ++ & +++ \\
\hline
\end{tabular}

Legend: +++ Strong (> 80\% in the evaluated methods); ++ Moderate (> 50\% in the evaluated methods).
Removal of biofilm at $\mathrm{pH} 6.0$ was higher than at $\mathrm{pH} 7.0$ (not shown), however all the results obtained were performed at $\mathrm{pH} 7.0$, according to the characteristics of the product. It was observed that E1 and E2 removed $65 \%$ and $55 \%$ of biomass, respectively, in $0.5 \mathrm{~h}$, regardless the enzyme dilution. However, at 2.0h of exposure time, $90 \%$ of biofilm removal was observed. In a joint action, independently of the enzyme dilution, E1 and E2 promoted $85 \%$ and $95 \%$ of cell death, respectively. Individually, the proteases did not show any increase in the cell death. Regardless the enzyme dilution and the exposure time, the increase of temperature from $30^{\circ} \mathrm{C}$ to $45^{\circ} \mathrm{C}$ did not promote significant changes in the biomass removal. On the other hand, the cell death was strongly affected by the association of exposure time and temperature.

\section{Conclusions}

Our results suggest the importance of a detailed study of the influence of $\mathrm{pH}$, temperature and exposure time to improve the bacterial biofilm removal and cell death, two essential factors for an effective cleaning of medical devices.

\section{Acknowledgement}

We thank CNPq for the financial support (Process $\mathrm{n}^{\circ}$ 467903/2014-0), Instituto Federal de Educação, Ciência e Tecnologia de São Paulo, for assistance through the $\mathrm{PIBIC/PIBIT/CNPQ/IFSP}$ program, and Universidade Estadual de Campinas.

1 Stiefel, P.; Rosenberg, U.; Schneider, J.; Mauerhofer, S.; ManiuraWeber, K.; Ren, Q. Appl. Microbiol. Biotechnol. 2016, 100, 4135.

2 Stiefel, P.; Mauerhofer, S.; Schneider, J.; Maniura-Weber, K.; Rosenberg, U.; Ren, Q. Antimicrob. Ag. Chemother. 2016, 60, 3647. 